\title{
Mixed Plastic aModern Convenience and an Environmental Nuisance
}

\author{
Kadafa, A.A ${ }^{1}$, Ayuba, H.K ${ }^{1}$ and Idris N.M ${ }^{1}$ \\ ${ }^{l}$ Department of Geography, Faculty of Social Sciences.NasarawaState University Keffi, Nigeria.
}

\begin{abstract}
Plastic waste is found in all types and forms (mixed plastic) mostly from packaging material for commercial product, thus resulting in its abundance in municipal solid waste. In the developed and developing countries high quantities of mixed plastic waste are generated but in the developed countries extensive recycling and reuse strategies have been implemented toward minimizing its quantity in waste flow and that which requires final disposal. In the developing countries where the concept of recycling is just coming up or waste collection from generation sources is a major problem, thus recycling is found only informally and carried out by scavengers. In Nigeria the greatest environmental issue is solid waste management and the most difficult fraction to handle is mixed plastic. Due to its high generation since it is the most common packing material used by manufacturer within the country. Polypropylene (PP/5) found in confectionery packets and Polyethylene Terephthalate (PETE/1) found in soft drinks bottles are the most commonly generated plastic in Nigeria, thus can be found in abundance littering the streets. Its high quantity generated and its non-degradable characteristic make it a serious environmental challenge inNigeria. This paper looks at mixed plastic waste inNigeria and its environmental hazard. With the aim of bring into view the issue of plastic waste management and its current nuisance and hazard on the streets of Nigeria.
\end{abstract}

Keywords: Mixed Plastic, Waste, Management, Abuja, Nigeria

\section{Introduction}

A communities needs were very practical and basic, with waste management consisting of mostly food waste before the industrial revolution. The industrial revolution brought about a drastic change in societies needs and wants. Plastic was nonexistent before this period. The emergency of plastic and its usage in the production sector was greatly influenced by its; low cost of production, wide and varied application, functionality and convenience, light weight, extreme durability, hygienic benefits. Its acceptance in the community was also influenced by the current era industrialization as of that period, increasing urbanization, increasing population, economic growth and social influences. The pending effects were not foreseen then.

Presently even with the knowledge of the environmental impacts of plastic its usage is still quite extensive in food and beverage production, pharmaceutical, agriculture and medicine.

Since the 1970s, the consumption of plastics has grown dramatically. Consequently, resulting in the creation of waste plastics andthere has been a steady increase in the use of plastic products resulting in a proportionate rise in plastic waste in solid waste streams (Ebo,et al. 2015). Plastic waste is now a common component of municipal solid waste which is found in high quantities due to its extensive usage as packaging material for food and drinks. The proportion of plastic waste in waste streams has continual increase due to the huge demand for plastic products in the majority of countries (Ebo,et al. 2015). Plastic packaging and bags accounted for the main share of plastic waste and are very difficult to separate from the waste stream (Nguyen,et al. 2010).

There are over 100 different types of plastic waste but seven types of plastic are commonly found in municipal solid waste;

1. Polyethylene Terephthalate (PETE/1) - e.g. Soft drinks bottles, video tapes, X-ray film

2. High Density Polyethylene (HDPE/2) - e.g. Detergent bottles, pipes

3. Low Density Polyethylene (LDPE/4) - e.g. Clingfilm, Playground slides

4. Polyvinyl Chloride $(\mathrm{PVC} / 3)$ - e.g. Insulation on electric wires

5. Polypropylene (PP/5) - e.g. Hinges, Lids of confectionery packets.

6. Polystyrene (PS/6)

7. Other multilayered plastic materials (7)

Plastic waste litters the environment and is transported by wind to other areas inclusive of remote areas (Jalil,et al. 2013). Its littering of the environment reduces the beauty and is Aesthetic unpleasing (Legesse and Diriba, 2011). There had been cases where large turtles of the endangered species had been found to have suffocated due to mistakenly swallowing plastic sheets mixed with seaweeds (Thiel,et al. 2003; UNEP, 2005). Researches have carried out experiments where the chemical constituents of the plastic food packaging have been found to leach into the food product especially high temperature food. Also in the field of agriculture, it 
was found to affecting crops. Ranging from reduction in soil aeration and penetration, reduction in water infiltration due to high bulk density, reduced plant growth and yield (Deguchi,et al. 1997, Mbah,et al. 2004, Agbede,et al. 2008, Tokiwa,et al. 2009, Nwachukwu,et al. 2010 and Atuanya, et al. 2012). They have also caused blockage of wastewater pipes and drainage pipes and artificial flooding due to blocked drainages (Legesse and Diriba, 2011).

\section{Materials And Methods}

In research Abuja is selected as representative of the current plastic waste management situation in Nigeria. Abuja; Nigeria's capital city is located in the middle of the country. It falls within latitude $7^{\circ} 25^{\prime} \mathrm{N}$ and $9^{\circ} 20^{\circ}$ North of the Equator and longitude $5^{\circ} 45^{\prime}$ and $7^{\circ} 39^{\prime}$ (www.fct.gov.ng). Abuja has a gentle undulating terrain rising from $305 \mathrm{~m}$ above sea level in the west to $610 \mathrm{~m}$ above sea level in the east, interlaced by riverine depressions of the Usman River and its tributaries (Abuja-Citiserve, 2004).Preliminary studies was carried out to grasp an overview of the research; this was carried out through literature review and exploratory field survey. The literature review consists of general waste management issues. The exploratory field survey consists of site visit to case study areas and observations. Data was collected using field survey; questionnaires and observations.

\section{Findings/Discussions}

In developed countries where extensive recycling programs have be establish and are fully operation, plastic waste stream isn't a problem. In African developing countries where formal recycling isn't establish or operational this possesses a problem. With high volumes of mixed plastics being generated, in 2004 the Federal Ministry Of Environment Abuja, Nigeria report estimated the plastic waste fraction for six districtsin Abuja; Gorki, Wuse, Apo, Gwarimpa, Maitama And Asokoroas 18.1\%. In 2012, Abuja Environmental Protection Board characterized waste composition for Abuja, Nigeria with mixed plastic quantities at 14,615.5106 tons/year making up 18\% fraction of waste generated (Figure 1). This percentage only represent the $43 \%$ waste collected from a population of over 4million as of 2012(NPC, 2012 and Kadafa,et al, 2013).



Figure 1: Municipal Waste Characterization for the Federal Capital City (Source: Abuja Environmental Protection Board, 2012)

In Abuja the solid waste collection services is only $43 \%$ by Abuja environmental protection board (AEPB) contractors and the municipal area council, with $65.7 \%$ of the population disposing their waste by dumping in open areasas shown in Figure 2.

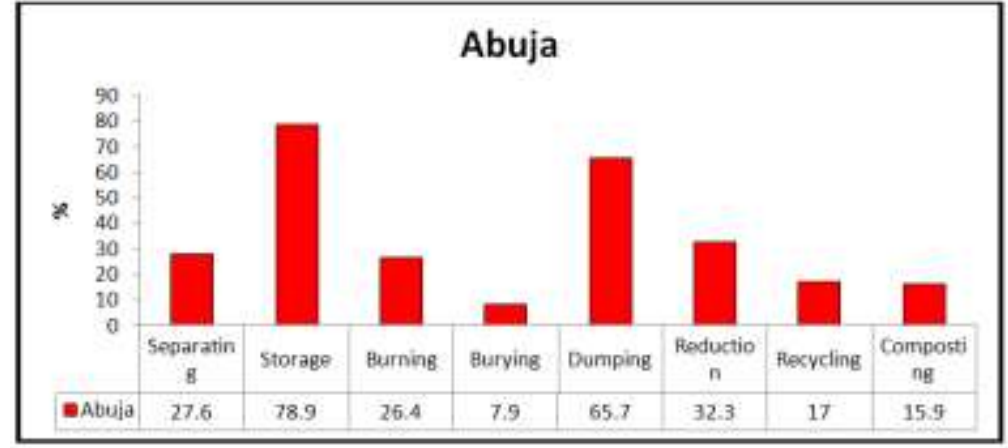

Figure 2: Frequency Based on Solid Waste Management Practices 
This results in large quantities of waste on the streets. Since plastic waste is non-biodegradable, this waste fraction ispersistent and can be seen littering most streets in Abuja. Even when collected to the landfill and buried is remains persistent and unchanging. Figure 3 showspolyethylene after 13 years of burial the polyethylene waste is unchanged as the day initially buried. The cost of recycling polyethylene is higher than the cost of producing new polyethylene which makes it non-profitable to consider recycling. The manufactures have a high preference for polyethylene as such it is mostly used for the packaging of their products, which is in high demand such as drinks, water and other food products. The use of glass bottles which is usually recycled and reused by the manufacturing companies is being phased out. As such, currently this has been a source of great concern due to the high volume of polyethylene ending up in the dumpsites and on the streets.

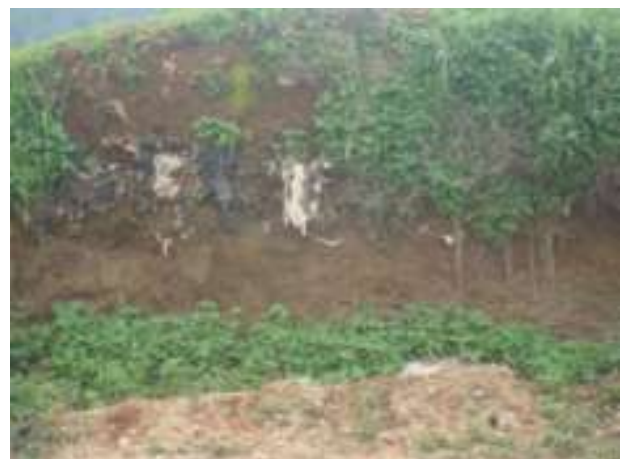

Figure 3: Polyethylene Buried 13 Years Ago in Mpape Dumpsite

(Source:Kadafaet al, 2013)

Currently waste segregation and recycling is not practiced in Abuja by AEPB. Segregation and recycling is carried out by independent scavenges within the dumpsite as shown in the Figure $\mathbf{4}$ and $\mathbf{5}$. The scavengers sort out the waste components after the contractors tip the waste. They sell the collected items in bulk to companies located in different parts of Nigeria. AEPB needs to utilize this avenue as a means of generating revenue toward facilitating waste management operations.



Figure 4: Scavengers Collecting Recyclable Items from Tipped Waste at Gosa Dumpsite

(Source:Kadafaet al, 2013)

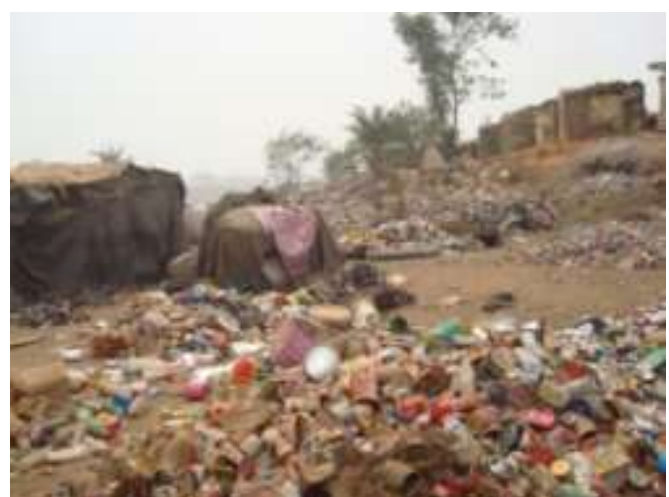

Figure 5: Collection of Recyclable Item by Scavengers within Gosa Dumpsite

(Source:Kadafa, et al, 2013) 
Also individual sell recyclable items to scavengers thus the survey carried out shows $17 \%$ respondent recycle informally leaving $83 \%$ of a population of over 4 million not recycling as shown in Figure 2

\section{Conclusion}

It is quite difficult to control the consumption patterns of individual, with more pressing issues; such as hunger and poverty. But the usage of mixed plastic in production process can be regulated with more ease thereby minimizing the quantities that end up on the streets

\section{Recommendation}

Regulation of the production of polypropylene and all its categories in the production sector with stringent penalties

\section{References}

[1]. Abdul Jalil, NannuMian and Muhammad Khalilur Rahman (2013). Using Plastic Bags and Its Damaging Impact on Environment and Agriculture:An Alternative Proposal. International Journal of Learning \& Development, 3(4).

[2]. Abuja-Citiserve. (2004). Estimates of Waste Generation Volumes and Income Potential in Abuja. Population Abuja (English Edition), 805:1-29. http://www.slgpnigeria.org/uploads/File/805.pdf. Acessed. 16th April 2012

[3]. Agbede, T.M., Ojeniyi, S.O. and Adeyemo, A.J. (2008). Effect of Poultry Manure on SoilPhysical and Chemical Properties, Growth and Grain Yield of Sorghum in South West Nigeria. American Eurasian Journal of Sustainable Agriculture, 2(1): $72-77$.

[4]. Atuanya, E.I., Aborisade, W.T. and Nwogu, N.A. (2012). Impact of Plastic Enriched Composting on Soil Structure, Fertility and Growth of Maize Plants. European Journal of Applied Sciences 4 (3): 105-109. DOI: 10.5829/idosi.ejas.2012.4.3.270.

[5]. Deguchi, T., Y. Kiitaoka, M. Kakzawa and T. Nishida (1997). Nylon biodegradation by lignin degrading fungi. Applied and Environmental Microbiology, 63(1): 329-331.

[6]. Ebo, T.Q., Hero, T., Kwasi, A., Baffour, D.and Ilona, O.(2015). Theoretical Framework for Plastic Waste Management in Ghana through Extended Producer Responsibility: Case of Sachet Water Waste. Int. J. Environ. Res. Public Health, 12, 9907-9919.

[7]. Kadafa, A.A, Latifah, AbdManaf, Abdullah, Ho Sabrina, Sulaiman, Wan NurAzmin (2012). A Review on Municipal Solid Waste Management in Nigeria, Journal of American Science, 8(12):975-982.

[8]. Kadafa, A.A, Latifah, AbdManaf, Abdullah, Ho Sabrina, Sulaiman, Wan NurAzmin (2013). Current Status of Municipal Solid Waste Management Practise in FCT Abuja, Research Journal of Environmental and Earth Sciences, 5(6):295-304

[9]. Legesse, A. and Diriba, M. (2011). Survey on the Usage of Plastic Bags, their Disposal and Adverse Impacts on Environment: A Case Study in Jimma City, Southwestern Ethiopia, Journal of Toxicology and Environmental Health Sciences. 3(8) pp. $234-248$.

[10]. Mbah, C.N., Mbagwu, J.S.C. Onya, V.M. and Anikwe, M.A.N. (2004). Effect of Application of Biofertilizers on Soil Densification, Total Porosity, Aggregate stability and Maize Gain Yield in Dystric Leptoso at Abakiliki, Nigeria. Journal of Science and Technology, 10: 74-85

[11]. Nguyen Phuc Thanh, Yasuhiro Matsui and Takeshi Fujiwara (2011).Assessment of Plastic Waste Generation and its Potential Recycling of Household Solid Waste in Can Tho City, Vietnam. Environ Monit Assess, 175:23-35.

[12]. NPC. (2012). National Population Commission Nigeria. Retrieved from www.population.gov.ng. Accessed 16 th April 2012.

[13]. Nwachukwu, S., O. Obidi and C. Odocha, 2010. Occurrence and Recalcitrance of Polythene Bag Waste in Nigeria Soils. African Journal of Biotechnology9(37): 6096-6104.

[14]. Thiel, M., Hinojosa,I.,Vásquez, N. and Macaya, E. (2003). Floating Marin Debris in Coastal Waters of the SE-Pacific (Chile). Marine Pollution Bulletin 46: 224-231.

[15]. Tokiwa, Y., B.P. Calabia, U.C. Ugwu and S. Aiba 2009. Biodegradability of plastics. International Journal of Molecular Sciences, 10: 3723-3742.

[16]. United Nation Environmental Program (UNEP). (2005). Marine Litter: An Analytical Overview. http://www.unep.org/regionalseas/marinelitter/publications/docs/anl_oview.pdf 